\title{
Pengaruh Profitabilitas, Ukuran Perusahaan, dan Kepemilikan Manajerial terhadap Praktik Perataan Laba (Income Smoothing)
}

\author{
Ngurah Surya Maotama1 \\ Fakultas Ekonomi dan Bisnis \\ Universitas Udayana, Indonesia \\ Email: smaotama@gmail.com
}

\author{
Ida Bagus Putra Astika2 \\ Fakultas Ekonomi dan Bisnis \\ Universitas Udayana, Indonesia
}

\begin{abstract}
ABSTRAK
Penelitian bertujuan untuk mendapatkan bukti empiris mengenai pengaruh profitabiitas, ukuran perusahaan, dan kepemilikan manajerial terhadap praktik perataan laba (Income Smoothing). Penelitianini dilakukan pada perusahaan property dan real estate yang terdaftar di Bursa Efek Indonesia tahun 2015-2018. Teknik pengambilan sampel menggunakan metode purprosive sampling diperoleh 18 perusahaan terpilih untuk dijadikan sampeldengan 3 tahun pengamatan sehingga didapatkan jumlah sampel sebanyak54.Pengujian hipotesis diujikan menggunakan teknik analisis regresi logistik.Berdasarkan hasil analisis regresi logistik diperoleh bahwa profitabilitas, ukuran perusahaan, dan kepemilikan manajerial berpengaruh positif terhadap praktik perataan laba (Income Smoohing).

Kata Kunci: Praktik Perataan Laba; Profitabilitas; Ukuran Perusahaan; Kepemilikan Manajerial.

The Effect of Profitability, Company Size, and Managerial Ownership on Income Smoothing Practices
\end{abstract}

\section{ABSTRACT}

The research aims to obtain empirical evidence about the effect of profitability, company size, and managerial ownership on income smoothing practices (Income Smoothing). This research was conducted at property and real estate companies listed on the Indonesia Stock Exchange in 2015-2018. Sampling technique using purprosive sampling method obtained 18 selected companies to be sampled with 3 years of observation so as to get a total sample of 54 . Hypothesis testing was tested using logistic regression analysis techniques. positive about income smoothing practices (Income Smoohing).

Keywords: Income Smoothing Practices; Profitability; Company Size; Managerial ownership.

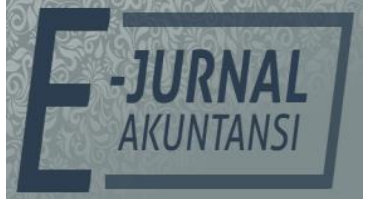

E-JA

e-Jurnal Akuntansi e-ISSN 2302-8556

Vol. 30 No. 7

Denpasar, Juli 2020

Hal.1767-1779

Artikel Masuk: 8 Januari 2020

Tanggal Diterima: 8 Juni 2020

The Article is Available in: https://ojs.unud.ac.id/index.php/Akuntansi/index 


\section{PENDAHULUAN}

Praktik Perataan laba merupakan fenomena yang telah banyak dilakukan di berbagai negara. Banyak yang memperdebatkan apakah perataan laba itu baik atau buruk, serta mengapa perataan laba ini banyak dan boleh dilakukan. Perataan laba tidak menjadi masalah untuk dilakukan selama dalam pelaksanaannya tidak mengandung fraud (Wijoyo, 2014). Tindakan manajemen untuk melakukan perataan laba umumnya didasarkan atas ber bagai alasan baik untuk memuaskan kepentingan pemilik perusahaan, seperti menaikkan nilai perusahaan, sehingga muncul anggapan bahwa perusahaan yang bersangkutan memiliki risiko yang rendah dalam menaikkan harga saham perusahaan maupun untuk memuaskan kepentingannya sendiri (opportunistic) seperti mendapatkan bonus dan mempertahakan posisi jabatannya. Jadi meskipun manajemen memiliki tujuan dan alasan, praktik perataan laba mengakibatkan pengungkapan dalam laporan keuangan tidak memadai.Hal ini dikarenakan manajemen merubah kandungan informasi atas laporan keuangan, sehingga pengguna laporan keuangan tidak memperoleh informasi yang akurat, oleh karena itu pengguna laporan keuangan perlu mewaspadai informasi yang tersaji dalam laporan keuangan.

Fenomena praktik perataan laba (income smoothing) sudah banyak terjadi pada perusahaan-perusahaan di Indonesia salah satunya adalah PT. Waskita Karya.Pada penghujung 2009, Waskita Karya menjadi sorotan karena kasus manipulasi laporan keuangan. Dimana terjadi kelebihan pencatatan pada laporan keuangan 2004-2007. Pada rentang waktu itu PT. Waskita Karya seharusnya mencatat rugi, namun dalam laporannya malah terlihat untung.Hal ini disebabkan karena direksi melakukan rekayasa keuangan sejak tahun buku 2004-2007 dengan memasukkan proyeksi multitahun kedepan sebagai pendapatan tertentu.Pemalsuan keuangan perusahaan ini terdeteksi sejak Agustus 2009 dan menyebabkan PT. Waskita Karya mengalami defisit modal sebesar Rp475 miliar. Rekayasa laporan keuangan BUMN bidang jasa konstruksi ini hanya bersifat administrative (accounting). Oknum direksi yang terlibat, diakui tidak secara sengaja memalsukan laporan keuanagn guna kepentingan pribadi.Ini hanya pelanggaran standar sisi akuntansi saja. Kondisi perusahaan yang sulit menyebabkan merekan mencari jalan dengan memalsukan laporan (Detik Finance, 2014). Fenomena praktik perataan laba lainnya yang terjadi di Indonesia adalah PT Kimia Farma Tbk, yang merupakan perusahaan farmasi terbesar di Indonesia. Tahun 2002, Kimia Farma terbukti melakukan penggelembungan keuntungan, hal tersebut diketahui setelah dilakukan audit ulang atas laporan keuangan tanggal 31 Desember 2001 yang melaporkan adanya laba bersih sekitar Rp132 milyar, namun setelah dilakukan audit ulang ternyata laba perusahaan hanya sebesar Rp99,56 milyar, lebih rendah sebesar Rp32,6 milyar atau 24,7\% dari laba awal yang dilaporkan. Perbedaan saldo laba dikarenakan adanya 2 kesalahan, pertama kesalahan penyajian dasar berkaitan dengan persediaan yaitu harga persediaan di mark-up dan dijadikan dasar penilaian persediaan, yang kedua kesalahan dalam penyajian yang berkaitan dengan penjualan yaitu dengan dilakukannya pencatatan ganda atas penjualan.

Berdasarkan beberapa kasus yang melakukan praktik perataan laba dapat disimpulkan bahwa dalam perekonomian Indonesia, perataan laba sudah sering 
dilakukan oleh perusahaan. Tindakan tersebut dilakukan oleh perusahaan agar laporan keuangan perusahaan selalu terlihat baik sehingga para investor bisa meningkatkan investasinya pada perusahaan tersebut.Banyak faktor yang diduga dapat mempengaruhi praktik perataan laba (income smoothing) diantaranya profitabilitas, ukuran perusahaan, dan kepemilikan manajerial.Dimana faktor-faktor tersebut merupakan variabel independen dalam penelitian ini.

Profitabilitas menunjukkan kemampuan perusahaan dalam menghasilkan laba selama satu periode waktu tertentu.Pada umumnya nilai profitabilitas suatu perusahaan dapat digunakan sebagai indikator untuk mengukur kinerja suatu perusahaan. Oleh karena hal tersebut, keterkaitan antara profitabilitas dengan praktik perataan laba adalah ketika profitabilitas yang diperoleh perusahaan kecil pada periode waktu tertentu akan memicu perusahaan untuk melakukan praktik perataan laba dengan cara meningkatkan pendapatan yang diperoleh sehingga akan memperlihatkan saham dan mempertahankan investor yang ada. Pradnyandari \& Astika (2019) menemukan pula bahwa profitabilitas berpengaruh positif terhadap praktik perataan laba. Artinya tanda positif tersebut semakin tinggi profitabilitas maka semakin meningkat praktik perataan laba yang terjadi dan sebaliknya semakin rendah profitabilitas maka semakin rendah praktik perataan laba.

Perkembangan ukuran suatu perusahaan sangat mempengaruhi perhatian dan ketertarikan para analis, investor maupun pemerintah dalam menilai kelangsungan perusahaan kedepannya. Ukuran perusahaan pada penelitian ini diukur dengan total aset yang dimiliki oleh perusahaan. Menurut Peranasari \& Dharmadiaksa (2014) semakin besar ukuran suatu perusahaan maka semakin banyak mendapatkan perhatian baik dari para analisis, investor maupun pemerintah. Perusahaan cenderung akan menghindari fluktuasi laba yang drastis, karena perusahaan nantinya akan dibebani pajak yang besar dan juga untuk menghindari permintaan kenaikkan gaji dan serikat. Di samping itu, ukuran perusahaan dapat mempengaruhi tindakan manajer di dalam melakukan perataan laba. Semakin besarnya ukuran suatu perusahaan, maka perusahaan dapat memberikan informasi yang lebih transparan dan lengkap mengenai perusahaannya, demikian sebaliknya semakin kecil ukuran perusahaan, maka informasi yang disampaikan tidak begitu transparan. Perusahaan yang ukurannya lebih besar diperkirakan memiliki kecenderungan yang lebih besar untuk melakukan perataan laba (Iskandar \& Suardana, 2016). Hal ini terjadi karena perusahaan besar mendapatkan pengawasan yang lebih ketat dari investor.Untuk itu, perusahaan besar kemungkinan melakukan praktik perataan laba untuk mengurangi fluktuasi laba yang besar.Hal ini dilakukan karena fluktuasi laba yang besar menunjukkan risiko yang besar dalam investasi sehingga mempengaruhi kepercayaan investor terhadap perusahaan.Dengan demikian, semakin besar ukuran perusahaan maka semakin besar kemungkinan menajemen melakukan praktik perataan laba. Dalam penelitian yang dilakukan oleh Oktaviasari et al. (2018), dan Ayunika \&Yadnyana (2018) menyimpulkan hasil bahwa ukuran perusahaan berpengaruh positif terhadap praktik perataan laba. Hasil tersebut berarti bahwa perusahaan yang memiliki ukuran yang besar memiliki dorongan yang lebih besar untuk melakukan perataan laba 
Manajemen sebagai pengelola perusahaan memiliki informasi lebih dibandingkan dengan pemegang saham. Hal ini menyebabkan terjadinya asimetri informasi. Kepemilikan manajerial adalah persentase kepemilikan saham pada perusahaan oleh pihak manajerial. Manajer yang sekaligus pemegang saham akan berusaha bekerja secara optimal dan tidak hanya mementingkan kepentingannya sendiri. Manajemen selalu berupaya meningkatkan kinerja dan nilai perusahaan karena dengan meningkatkan kinerja dan nilai perusahaan maka kekayaannya yang dimiliki sebagai pemegang saham akan meningkat, sehingga kesejahteraan pemegang saham akan meningkat pula. Penelitian-penelitian sebelumnya menunjukkan hasil yang tidak konsisten megenai pengaruh kepemilikan manajerial pada manajemen laba. Cahyaningsih et al. (2014) dalam penelitiannya juga menyatakan bahwa kepemilikan manajerial berpengaruh positif terhadap praktik perataan laba. Kepemilikan manajerial akan menjadi perhatian karena persentase kepemilikan manajerial akan mempengaruhi kinerja perusahaan dan akan berdampak pula pada nilai perusahaan.

Penelitian terhadap faktor yang berpengaruh terhadap perataan laba ini dilakukan peneliti dengan memilih sampel pada perusahaan property dan real estate yang terdaftar di Bursa Efek Indonesia. Dipilihnya perusahaan property dan real estate sebagai sampel dalam penelitian karena perkembangan bisnis properti di Indonesia berkembang makin pesat yang ditandai dengan banyaknya pembangunan gedung-gedung perkantoran, perumahan, dan juga pusat perbelanjaan. Bisnis property juga merupakan usaha yang dipastikan tidak akan mati, mengingat makin besarnya angka pertumbuhan penduduk di Indonesia yang menyebabkan meningkatnya kebutuhan akan tempat tinggal, perkanto ran, dan pusat perbelanjaan. Perkembangan bisnis properti diperkirakan akan tumbuh 200 persen sepanjang tahun 2011 sampai 2021, dengan total kontribusi properti Indonesia mencapai 2,5\% pasar global (Pefindo, 2013).

Profitabilitas merupakan rasio yang menunjukkan tingkat kemampuan perusahaan dalam menghasilkan laba. Semakin tinggi rasio profitabilitas semakin baik pula tingkat efektivitas manajemen suatu perusahaan dalam menghasilkan laba. Pada umumnya nilai profitabilitas suatu perusahaan dapat digunakan sebagai indikator untuk mengukur kinerja suatu perusahaan. Semakin tinggi profitabilitas suatu perusahaan maka kinerja dan kemampuan perusahaan dalam menghasilkan laba juga meningkat. Keterkaitan antara profitabilitas dengan manajemen laba adalah ketika profitabilitas yang diperoleh perusahaan kecil pada periode waktu tertentu akan memicu perusahaan untuk melakukan manajemen laba dengan cara meningkatkan pendapatan yang diperoleh sehingga akan memperlihatkan saham dan mempertahakan investor yang ada. Pradnyandari \& Astika (2019) menemukan pula bahwa profitabilitas berpengaruh positif terhadap praktik perataan laba. Artinya tanda positif tersebut semakin tinggi profitabilitas maka semakin meningkat praktik perataan laba yang terjadi dan sebaliknya semakin rendah profitabilitas maka semakin rendah praktik perataan laba. Berdasarkan uraian tersebut, maka hipotesis yang diajukan sebagai berikut.

$\mathrm{H}_{1}$ : Profitabilitas berpengaruh positif terhadap praktik perataan laba. 
Ukuran perusahaan adalah skala pengukuran perusahaan yang dilihat dari total aset yang dimiliki perusahaan pada akhir tahun. Ukuran perusahaan biasanya diukur dengan log natural total aset perusahaan agar menghindari terjadinya fluktuasi secara berlebihan. Ukuran perusahaan diduga menjadi salah satu faktor yang mendorong manajemen untuk melakukan perataan laba. Perusahaan yang besar lebih diperhatikan oleh masyarakat sehingga mereka akan lebih berhati- hati dalam melakukan pelaporan keuangan, sehingga berdampak perusahaan tersebut melaporkan kondisinya lebih akurat (Abiprayu \& Pangestuti, 2011). Dalam penelitian yang dilakukan oleh Oktaviasari et al. (2018), dan Ayunika \& Yadnyana (2018) menyimpulkan hasil bahwa ukuran perusahaan berpengaruh positif terhadap praktik perataan laba. Berdasarkan uraian tersebut, maka hipotesis yang diajukan adalah sebagai berikut.

$\mathrm{H}_{2}$ : Ukuran perusahaan berpengaruh positif terhadap praktik perataan laba.

Teori agensi menjelaskan adanya pemisahan antara pemilik dan pengelola. Hal ini akan menimbulkan masalah agensi (agency problem). Untuk mengurangi malasah agensi tersebut Jensen \& Meckling (1976).mengidentifikasi perlu dilakukan pengawasan atau monitoring salah satunya melalui kepemilikan manajemen. Kepemilikan saham perusahaan oleh manajemen, menyebabkan manajemen merasakan langsung manfaat dari keputusan yang diambil. Karena, kepemilikan ini akan mensejajarkan antara kepentingan manajemen dan pemegang saham (Jensen \& Meckling, 1976).

Mahariana \& Ramantha (2014) menyatakan bahwa adanya peningkatan kepemilikan saham oleh manajer dalam perusahaan akan mampu menciptakan kinerja perusahaan secara optimal dan memotivasi manajer dalam bertindak agar lebih berhati-hati, karena manajer ikut menanggung konsekuensi dari setiap tindakan yang dilakukannya. Cahyaningsih et al. (2014) dalam penelitiannya juga menyatakan bahwa kepemilikan manajerial berpengaruh positif terhadap praktik perataan laba. Kepemilikan manajerial akan menjadi perhatian karena persentase kepemilikan manajerial akan mempengaruhi kinerja perusahaan dan akan berdampak pula pada nilai perusahaan.

$\mathrm{H}_{3}$ : Kepemilikan manajerial berpengaruh positif terhadap praktik perataan laba.

\section{METODE PENELITIAN}

Lokasi penelitian merupakan suatu tempat atau wilayah dimana penelitian tersebut dilakukan. Penelitian ini dilakukan di Bursa Efek Indonesia dengan mengakses website www.idx.co.id. dan mengunduh laporan tahunan perusahaan property dan real estate tahun 2015-2018.

Populasi dalam penelitian ini adalah seluruh perusahaan property dan real estate yang terdaftar di Bursa Efek Indonesia selama periode 2015-2018.Sampel ditentukan dengan metode non prabibility sampling dengan teknik purposive sampling. Adapun kriteria yang digunakan adalah perusahaan property dan real estateyang menyajikan annual report dan laporan keuangan berturut-turut selama 2015-2018.

Teknik analisis pada penelitian ini menggunakan analisis regresi logistik melalui program SPSS. Adapun persamaan regresi yang terbentuk yaitu sebagai berikut. 


$\begin{array}{ll}\operatorname{Ln}\left(\frac{p}{1-p}\right)= & \alpha+\beta_{1} . \mathrm{X} 1+\beta_{2} . \mathrm{X} 2+\beta_{3} . \mathrm{X} 3+ \\ \mathrm{P}(\mathrm{Y}) & : \text { Income Smoothing } \\ \mathrm{a} & \text { : Nilai konstanta } \\ \beta_{1}, \beta_{2}, \beta_{3} & \text { :Koefisien regresi masing-masing faktor } \\ \mathrm{X} 1 & : \text { Profitabilitas } \\ \mathrm{X} 2 & \text { : Ukuran perusahaan } \\ \mathrm{X} 3 & \text { : Kepemilikan manajerial } \\ \Sigma & \text { : error }\end{array}$

\section{HASIL DAN PEMBAHASAN}

Variabel Income Smoothing (Y) adalah perataan laba yang memiliki nilai minimum 0 dan nilai maksimum 1 . Hal ini menunjukkan variabel perataan laba merupakan variabel dummy dimana angka 0 menunjukkan perusahaan tidak melakukan praktik perataan laba dan angka 1 perusahaan melakukan perataan laba. Dengan nilai rata-rata 0,52 perusahaan yang menjadi sampel melakukan perataan laba. Untuk standar deviasi sebesar 0,504. Hal ini menunjukkan perbandingan perbedaan yang diteliti dalam melakukan praktik perataan laba (income smoothing).Variabel Profitabilitas (X1) diperoleh nilai minimum sebesar 0,0551 sedangkan nilai maksimum sebesar 0,1814. Sehingga secara keseluruhan didapatkan variabel profitabilitas memiliki rata-rata sebesar 0,040984 dan standar deviasi 0,512904.Variabel Ukuran Perusahaan (X2) diperoleh nilai minimum sebesar 22,0920 sedangkan nilai maksimum sebesar 30,1610. Sehingga secara keseluruhan didapatkan variabel ukuran perusahaan memiliki rata-rata sebesar 26,861556 dan standar deviasi 2,9364998. Variabel Kepemilikan Manajerial (X3) diperoleh nilai minimum sebesar 0,000 sedangkan nilai maksimum sebesar 0,6682. Sehingga secara keseluruhan didapatkan variabel kepemilikan manajerial memiliki rata-rata sebesar 0,105921 dan standar deviasi 0,1961277.

Tabel 1. Hasil Statistik Deskripstif Variabel Penelitian

\begin{tabular}{lllll}
\hline & $\begin{array}{l}\text { Return On } \\
\text { Asset }\end{array}$ & \multicolumn{2}{l}{ Ukuran PerusahaanManajerial } & $\begin{array}{l}\text { Kepemilikan } \\
\text { Smoothing }\end{array}$ \\
\hline $\mathrm{N} \quad$ Valid & 54 & 54 & 54 & 54 \\
\multicolumn{1}{c}{ Missing } & 0 & 0 & 0 & 0 \\
Mean &, 040984 & 26,861556 &, 105921 &, 52 \\
Std. Deviation &, 0512904 & 2,9364998 &, 1961277 &, 504 \\
Variance &, 003 & 8,623 &, 038 &, 254 \\
Minimum &,- 0551 & 22,0920 &, 0000 & 0 \\
Maximum &, 1814 & 30,1610 &, 6682 & 1 \\
\hline
\end{tabular}

Sumber: Data Penelitian, 2019

Analisis regresi logistik digunakan karena variabel terikat dalam penelitian ini merupakan variabel dummy, yaitu perusahaan yang melakukan praktik perataan laba (income smoothing). Pengujian yang dilakukan ini melalui program SPSS pada tingkat signifikan 0,05 (5\%). Berikut tahapan-tahapan hasil dari analisis regresi logistik.

Kelayakan model regresi dinilai menggunakan uji Homser and Lemeshow. Uji Homser and Lemeshow menguji hipotesis nol bahwa data empiris cocok atau sesuai dengan model (tidak ada perbedaan antara model dengan data sehingga 
model dikatakan fit). Jika nilai menunjukkan signifikan Uji Homser and Lemeshow lebih besar dari 0,05 maka hipotesis 0 diterima dan berarti model mampu memprediksi nilai observasinya. Pada Tabel 2, akan disajikan tabel uji Homser and Lemeshow:

Tabel 2. Hasil Uji Homser and Lemesh

\begin{tabular}{llll}
\hline Step & Chi-square & df & Sig. \\
\hline 1 & 8,331 & 8 & 402 \\
\hline Sumber: Data Penelitian, 2019 &
\end{tabular}

Berdasarkan hasil analisis pada Tabel 2, diperoleh bahwa nilai dari uji Homser and Lemeshow yang diukur dengan nilai Chi Square sebesar 8,331 dengan nilai signifikansi sebesar 0,402. Hal ini menunjukkan nilai signifikansi 0,402 > 0,05 sehingga hipotesis nol diterima dan berarti model mampu memprediksi nilai observasinya.

Pengujian ini dilakukan dengan cara membandingkan nilai antara -2 Log Likelihood $(-2 \mathrm{LL})$ pada awal (block number $=0$ ) dan nilai -2 Log Likelihood pada akhir (block number $=1$ ). Jika terjadi penurunan nilai -2 Log Likelihood (-2LL), maka ini menunjukkan model regresi yang baik atau yang disebut dengan model sesuai dengan data yang dihipotesiskan. Hasil pengujian ditampilkan dalam Tabel 3, sebagai berikut.

Tabel 3. Perbandingan nilai -2LL Awal dengan -2LL Akhir

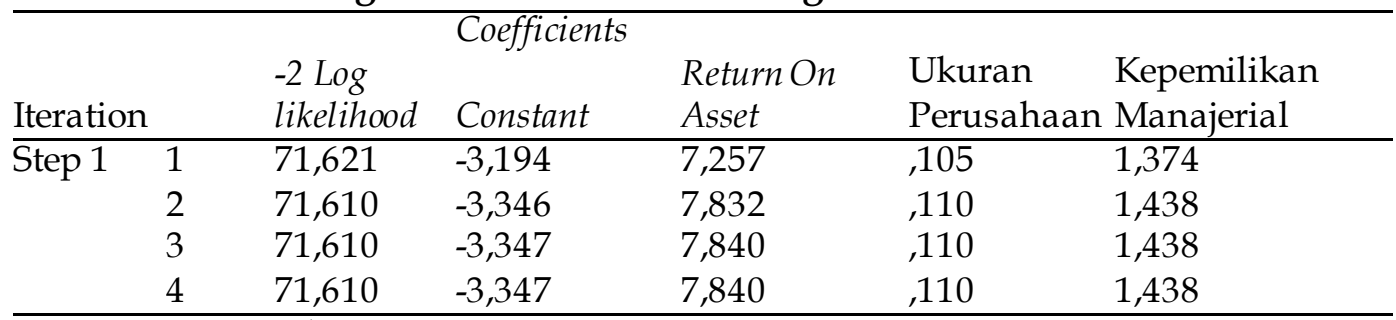

Sumber: Data Penelitian, 2019

Berdasarkan hasil analisis pada Tabel 3, diperoleh bahwa nilai -2 Log Likelihood (-2LL) pada awal sebesar 74,786 dan -2 Log Likelihood (-2LL) pada akhir sebesar 71,610 dan berdasarkan hasil tersebut terjadinya penurunan nilai. Penurunan nilai -2 Log Likelihood (-2LL) pada awal dan akhir menunjukkan model regresi yang lebih baik atau dengan kata lain model yang dihipotesiskan fit dengan data.

Besarnya nilai koefisien determinasi pada model regresi logistik ditunjukkan berdasarkan nilai Nagelkerke $R$ Square. Nilai Nagelkerke $R$ Square menunjukkan nilai variabilitas variabel dependen yang dapat dijelaskan oleh variabel independen, sedangkan sisanya dijelaskan oleh variabel-variabel lain diluar model penelitian ini. Hasil pengujian dapat ditampilkan dalam Tabel 4, sebagai berikut.

Tabel 4. Hasil Uji Koefisien Determinasi (Nagelkerke R Square)

\begin{tabular}{llll}
\hline \multicolumn{3}{c}{ Model Summary } \\
\hline Step & -2 Log likelihood & Cox \& Snell R Square & Nagelkerke R Square \\
\hline 1 & $71,610^{a}$ &, 557 &, 676 \\
\hline Sumber: Data Penelitian, 2019 &
\end{tabular}

Sumber: Data Penelitian, 2019

Berdasarkan hasil analisis pada Tabel 4, diperoleh bahwa nilai (Nagelkerke $R$ Square) yaitu 0,676 atau sama dengan 67,6\% yang berarti variabilitas variabel dependen yang dijelaskan oleh variabel independent yaitu sebesar 67,6\%, 
sedangkan sisanya sebesar 32,4\% dijelaskan dari variabel-variabel lain yang tidak dimasukkan atau diluar model penelitian ini.

Model analisis regresi logistik ini dibentuk dengan nilai estimasi parameter dalam Variabel dalam persamaan. Hasil pengujian dapat ditampilkan dalam Tabel 5, sebagai berikut.

Tabel 5. Variabel Dalam Persamaan

\begin{tabular}{|c|c|c|c|c|c|c|c|c|}
\hline & \multirow[b]{2}{*}{ B } & \multirow[b]{2}{*}{ S.E. } & \multirow[b]{2}{*}{ Wald } & \multirow[b]{2}{*}{$\mathrm{df}$} & \multirow[b]{2}{*}{ Sig. } & \multicolumn{2}{|c|}{ 95\% C.I.for EXP(B) } \\
\hline & & & & & & & Lower & Upper \\
\hline \multirow[t]{6}{*}{$\overline{\text { Step } 1^{\mathrm{a}}}$} & Return On Asset & 7,840 & 6,270 & 1,563 & 1 & 002 & 012 & 55242,612 \\
\hline & Ukuran & 110 & 098 & 1,254 & 1 & ,003 & 921 & 1,354 \\
\hline & Perusahaan & & & & & & & \\
\hline & Kepemilikan & 1,438 & 1,571 & 839 & 1 & ,004 & 194 & 91,520 \\
\hline & Manajerial & & & & & & & \\
\hline & Constant & 3,347 & 2,692 & 1,546 & 1 & 002 & & \\
\hline
\end{tabular}

Sumber: Data Penelitian, 2019

Berdasarkan hasil analisis Tabel 5, diperoleh bahwa pengujian model regresi yang terbentuk adalah sebagai berikut.

$$
\operatorname{Ln}\left(\frac{p}{1-p}\right)=3,347+7,840 \times 1+0,110 \times 2+1,438
$$

Variabel Profitabilitas menunjukkan koefisien regresi positif sebesar 7,840 dengan tingkat signifikansi sebesar 0,002. Nilai signifikansi uji t untuk variabel Profitabilitas sebesar 0,002 lebih kecil dari signifikansi 0,05 yang berarti hipotesis diterima. Jadi kesimpulan dari variabel Profitabilitas berpengaruh positif terhadap praktik perataan laba (income smoothing). Variabel Ukuran Perusahaan menunjukkan koefisien regresi positif sebesar 0,110 dengan tingkat signifikansi sebesar 0,003. Nilai signifikansi uji t untuk variabel Profitabilitas sebesar 0,003 lebih kecil dari signifikansi 0,05 yang berarti hipotesis diterima. Jadi kesimpulan dari variabel Ukuran Perusahaan berpengaruh positif terhadap praktik perataan laba (income smoothing).Variabel Kepemilikan Manajerial menunjukkan koefisien regresi positif sebesar 1,438 dengan tingkat signifikansi sebesar 0,004. Nilai signifikansi uji $\mathrm{t}$ untuk variabel Profitabilitas sebesar 0,004 lebih kecil dari signifikansi 0,05 yang berarti hipotesis diterima. Jadi kesimpulan dari variabel Kepemilikan Manajerial berpengaruh positif terhadap praktik perataan laba (income smoothing).

Hasil penelitian terhadap hipotesis pertama dengan menggunakan regresi logistik menghasilkan bahwa Profitabilitas memiliki nilai koefisien positif sebesar 7,840 dengan tingkat signifikansi sebesar 0,002 lebih kecil dari a 0,05. Dengan memiliki arti bahwa Profitabilitas memiliki pengaruh positif terhadap praktik perataan laba (income smoothing) pada perusahaan property dan real estate yang terdaftar di Bursa Efek Indonesia periode 2015-2018, dan tingkat signifikansi terhadap praktik perataan laba dapat disimpulkan hasil penelitian $\mathrm{H}_{1}$ diterima.

Hal ini mencerminkan bahwa Profitabilitas yang diproksikan oleh Return On Asset (ROA) yang dimana hal tersebut menunjukkan semakin tinggi tingkat Return On Asset (ROA) yang dimiliki oleh perusahaan maka semakin tinggi pula kecenderungan para manajemen melakukan praktik perataan laba, keterkaitan antara profitabilitas dengan praktik perataan laba adalah ketika profitabilitas yang diperoleh perusahaan kecil pada periode waktu tertentu akan memicu 
perusahaan untuk melakukan praktik perataan laba dengan cara meningkatkan pendapatan yang diperoleh sehingga akan memperlihatkan saham dan mempertahankan investor yang ada. Dengan tingkat profitabilitas atau Return On Asset (ROA) yang tinggi akan memberikan keyakinan bagi investor untuk mengambil keputusan dalam berinvestasi. Hasil penelitian ini sejalan dengan penelitian Ayunika \& Yadnyana (2018) dan Pradnyandari \& Astika (2019), yang menyatakan bahwa profitabilitas yang diukur melalui Return On Asset (ROA) menunjukkan pengaruh positif terhadap praktik perataan laba.

Hasil penelitian terhadap hipotesis kedua dengan menggunakan regresi logistik menghasilkan bahwa Ukuran Perusahaan memiliki nilai koefisien positif sebesar 0,110 dengan tingkat signifikansi sebesar 0,003 lebih kecil dari a 0,05. Dengan memiliki arti bahwa Ukuran Perusahaan memiliki pengaruh positif terhadap praktik perataan laba (income smoothing) pada perusahaan property dan real estate yang terdaftar di Bursa Efek Indonesia periode 2015-2018, dan tingkat signifikansi terhadap praktik perataan laba dapat disimpulkan hasil penelitian $\mathrm{H}_{2}$ diterima.

Hal ini mencerminkan bahwa Ukuran Perusahaan yang diproksikan oleh Log Natural Total Aktiva yang dimana hal tersebut menunjukkan semakin besar Ukuran Perusahaan maka semakin banyak mendapatkan perhatian baik atau kesan yang baik untuk mempengaruhi ketertarikan bagi para investor untuk berinvestasi karena adanya segala informasi laporan keuangan atau perkembangan suatu perusahaan untuk menilai kelangsungan perusahaan kedepannya. Maka dari itu perusahaan yang memiliki Ukuran Perusahaan yang besar memiliki dorongan yang lebih besar untuk melakukan Praktik Perataan Laba (Income Smoothing). Hasil penelitian ini sejalan dengan penelitian oleh Oktaviasari et al. (2018) yang menyatakan bahwa Ukuran Perusahaan yang diukur melalui Log Natural Total Aktiva menunjukkan pengaruh positif terhadap praktik perataan laba.

Hasil penelitian terhadap hipotesis ketiga dengan menggunakan regresi logistik menghasilkan bahwa Kepemilikan Manajerial memiliki nilai koefisien positif sebesar 1,438 dengan tingkat signifikansi sebesar 0,004 lebih kecil dari a 0,05. Dengan memiliki arti bahwa Kepemilikan Manajerial memiliki pengaruh positif terhadap praktik perataan laba (income smoothing) pada perusahaan property dan real estate yang terdaftar di Bursa Efek Indonesia periode 2015-2018, dan tingkat signifikansi terhadap praktik perataan laba dapat disimpulkan hasil penelitian $\mathrm{H}_{3}$ diterima.

Kepemilikan manajerial menjadi perhatian karena persentase kepemilikan manajerial akan mempengaruhi kinerja perusahaan dan akan berdampak pula pada nilai perusahaan. Kepemilikan manajerial dipercaya memiliki kemampuan untuk mempengaruhi jalannya perusahaan yang nantinya dapat mempengaruhi kinerja suatu perusahaan. Kepemilikan manajerial akan memotivasi manajer untuk meningkatkan kinerjanya demi pemegang saham maupun dirinya sendiri. Manajemen akan lebih berhati - hati dalam hal pengambilan keputusan, karena manajemen sendiri yang akan merasakan manfaat maupun menanggung kerugian dari keputusan yang diambil. Semakin besar kepemilikan manajerial maka manajemen akan semakin leluasa dalam mengatur laporan keuangan dan melakukan perataan laba oleh sebab itu 
semakin tinggi Kepemilikan Manajerial suatu perusahaan maka semakin besar kecenderungan melakukan Praktik Perataan Laba (income smoothing). Hasil penelitian ini sejalan dengan penelitian oleh Cahyaningsih et al. (2014) yang menyatakan bahwa Kepemilikan Manajerial menunjukkan pengaruh positif terhadap praktik perataan laba.

\section{SIMPULAN}

Variabel Independen Profitabilitas berpengaruh positif terhadap praktik perataan laba dalam penelitian ini. Hal ini mencerminkan bahwa Profitabilitas yang diproksikan oleh Return On Asset (ROA) yang dimana hal tersebut menunjukkan semakin tinggi tingkat Return On Asset (ROA) yang dimiliki oleh perusahaan maka semakin tinggi pula kecenderungan para manajemen melakukan praktik perataan laba. Hasil ini juga mendukung teori sinyal yang menjelaskan bahwa tingkat profitabilitas yang tinggi dianggap sebagai sinyal yang baik (good news) karena perusahaan berada dalam kondisi yang baik, sedangkan tingkat profitabilitas yang rendah dianggap sebagai sinyal yang buruk (bad news).

Variabel independen kedua yaitu Ukuran Perusahaan berpengaruh positif terhadap praktik perataan laba dalam penelitian ini. Hal ini mencerminkan bahwa Ukuran Perusahaan yang diproksikan oleh log natural total aktiva yang dimana hal tersebut menunjukkan semakin besar ukuran perusahaan maka semakin banyak mendapatkan perhatian para investor. Maka dari itu perusahaan yang memiliki Ukuran Perusahaan yang besar memiliki dorongan yang lebih besar untuk melakukan Praktik Perataan Laba (Income Smoothing). Hasil ini juga mendukung teori akuntansi positif bahwa perusahaan besar dengan laba yang tinggi cenderung mengelola labanya dengan cara menurunkan laba yang dilaporkan, karena didasari oleh motivasi untuk mengurangi beban pajak perusahaan. Perusahaan kecil umumnya kurang memperoleh perhatian dan pengawasan ketat, sehingga manajer kurang termotivasi untuk melakukan perataan laba.

Variabel independen ketiga yaitu Kepemilikan Manajerial berpengaruh positif terhadap praktik perataan laba dalam penelitian ini.Hal ini mencerminkan bahwa Kepemilikan Manajerial yang diukur dengan persentase kepemilikan saham beredar yang dimiliki manajemen dari seluruh modal saham perusahaan yang beredar. Maka dari itu semakin besar kepemilikan manajerial maka manajemen akan semakin leluasa dalam mengatur laporan keuangan dan melakukan perataan laba, oleh sebab itu semakin tinggi kepemilikan manajerial suatu perusahaan maka semakin besar kecenderungan melakukan Praktik Perataan Laba (income smoothing). Hasil ini juga mendukung teori keagenan, yaitu perbedaan kepentingan antara pemegang saham dan manajer dapat mendorong manajer untuk bertindak secara oportunistik.

\section{REFERENSI}

Abiprayu, K. ., \& Pangestuti, I. R. D. (2011). Pengaruh Profitabilitas, Ukuran Perusahaan, Financial Leverage, Dividend Payout Ratio Terhadap Perataan Laba (Studi Kasus Pada Perusahaan Manufaktur yang Terdaftar di Bursa Efek Indonesia Tahun 2006-2009). Universitas Diponogoro. 
Adriani, P. I., Putri, I. G. A. M. A. D., \& Tenaya, G. A. I. (2018). Pengaruh Ukuran Perusahaan, Profitabilitas, Financial Leverage, dan Winner/Loser Stock pada Perataan Laba Perusahaan Manufaktur. E-Jurnal Akuntansi Universitas Udayana, 25(3), 1913-1938.

Alexandr, M. B., \& Anjani, W. K. (2014). Income Smoothing : Impact Factors, Evidence In Indonesia. International Journal of Small Business and Entrepreneurship Research, 3(1), 21-27.

Anthony, \& Govindrajan. (2005). Management Control System (Pertama). Jakarta: Salemba Empat.

Ayunika, N. P. N., \& Yadnyana, I. K. (2018). Pengaruh Ukuran Perusahaan, Profitabilitasdan Financial Leverage Terhadap Praktik Perataan Laba Pada Perusahaan Manufaktur. E-Jurnal Akuntansi Universitas Udayana, 25(3), 24022429.

Beattie, V., Brown, S., Ewers, D., John, B., Manson, S., Thomas, D., \& Turner, M. (1994). Extraordinary Items and Income Smoothing: a Positive Accounting Approach. Journal of Business Finance $\mathcal{E}$ Accounting, Vol. 21, pp. 791-811. https://doi.org/10.1111/j.1468-5957.1994.tb00349.x

Belkaouli, A. R. (2007). Accounting Theory (Buku 2) (Kelima). Jakarta: Salemba Empat.

Boediono, G. S. (2005). Kualitas Laba: Studi Pengaruh Mekanisme Corpomfe Governance dan Dampak Manajemen Laba Dengan Menggunakan Analisis Jalur. Corporate Governance, 8(1), 15-16.

Brigham, E. F., \& Houston, J. F. (2006). Dasar-Dasar Manajemen Keuangan. Jakarta: Salemba Empat.

Cahyaningsih, R. M. T., Arifati, R., \& Oemar, A. (2014). Pengaruh Struktur Kepemilikan Manajerial, Profitabilitas, Dividend Payout Ratio, Free Cash Flow, Struktur Aset, dan Leverage Operasi Terhadap Praktik Perataan Laba ( Studi pada Perusahaan Manufaktur Sektor Industri Barang Konsumsi yang Terdaftar di BEI Ta. Jurnal Akuntansi Universitas Pandanaran Semarang, 1(1), $1-30$.

Chung, R., Firth, M., \& Kim, J. B. (2005). Earnings management, surplus free cash flow, and external monitoring. Journal of Business Research, 58(6), 766-776. https://doi.org/10.1016/j.jbusres.2003.12.002

Corolina, \& Juniarti. (2005). Analisa Faktor - Faktor Yang Berpengaruh Terhadap Perataan Laba ( Income Smoothing ) Pada Perusahaan- Perusahaan Go Public. Jurnal Universitas Kri, 1(1), 148-161.

Detik Finance. (2014). Usai Manipulasi Keuangan, Waskita Karya Segera Direstukturisasi. Retrieved September 18, 2019, from Berita Ekonomi Bisnis website: https://finance.detik.com/berita-ekonomi-bisnis/d-1200038/usaimanipulasi-keuangan-waskita-karya-segera-direstukturisasi

Dolar, B. (2016). Income Smoothing Practices of Us Banks. The International Journal of Business and Finance Research, 10(1), 1-11.

Donaldson, L., \& Davis, J. H. (1991). Stewardship Theory or Agency Theory: Australian Journal of Management, 16(June 1991), 49-66. https://doi.org/10.1177/031289629101600103

Eisenhardt, K. (1989). Agency Theory: An Assessment and Review. Academy of Management Review, 14(1), 57-74. 
Fengju, X., Yari Fard, R., Ghassab Maher, L., \& Akhteghan, N. (2016). The relationship between financial leverage and profitability with an emphasis on income smoothing in Iran's capital market. European Online Journal of Natural and Social Sciences, 2(3), 156-164.

Fudenberg, D., \& Tirole, J. (1995). A Theory of Income and Dividend Smoothing Based on Incumbency Rents. Journal of Political Economy, 103(1), 75-93. https://doi.org/10.1086/261976

Gantino, R. (2015). Effect of Managerial Ownership Structure, Financial Risk and Its Value on Income Smoothing in the Automotive Industry and Food \& Beverage Industry Listed in Indonesia Stock Exchange. Research Journal of Finance and Accounting, 6(4), 48-56.

Ghozali, I. (2016). Aplikasi Analisis Multivariete Dengan Program IBM SPSS 23 (Edisi Delapan). Semarang: Badan Penerbit Universitas Diponegoro.

Ikatan Akuntansi Indonesia. (2009). Standar Akuntansi Keuangan PSAK No. 1: Penyajian Laporan Keuangan. Jakarta: Salemba Empat.

Iskandar, A., \& Suardana, K. (2016). Pengaruh Ukuran Perusahaan, Return on Asset, Dan Winner/Loser Stock Terhadap Praktik Perataan Laba. E-Jurnal Akuntansi, 14(2), 805-834.

Jensen, M. C., \& Meckling, W. H. (1976). THEORY OF THE FIRM: MANAGERIAL BEHAVIOR, AGENCY COSTS AND OWNERSHIP STRUCTURE Michael C. JENSEN and William H. MECKLING : Journal of Financial Economics, 3, 305-360.

Kasmir. (2016). Analisis Laporan Keuangan. Jakarta: PT. Rajagrafindo Persada.

Leuz, C., Nanda, D., \& Wysocki, P. D. (2003). Earnings management and investor protection: an international comparison. Journal of Financial Economics, 69(1), 505-527. https://doi.org/10.1016/S0304-405X(03)00121-1

Mahariana, I., \& Ramantha, I. (2014). Pengaruh Kepemilikan Manajerial Dan Kepemilikan Institusional Terhadap Manajemen Laba Pada Perusahaan Manufaktur Di Bei. E-Jurnal Akuntansi, 7(3), 688-699.

Nejad, H. S., Zeynali, S., \& Alavi, S. S. (2013). Investigation of Income Smoothing At the Companieslistedonthestock Exchange By the Using Index Eckel ( Case Study : Tehran Stock Exchange ). Asian Journal of Management Sciences and Educaition, 2(2), 49-62.

Oktaviasari, T., Miqdad, M., \& Effendi, R. (2018). Pengaruh Profitabilitas, Ukuran Perusahaan, dan Leverage Terhadap Perataan Laba pada Perusahaan Manufaktur di BEI. E-Journal Ekonomi Bisnis Dan Akuntansi, 5(1), 81-87.

Pefindo. (2013). Equity Research PT Alkindo Naratama Tbk (ALDO). Retrieved from ttps://www.idx.co.id/Portals/0/StaticData/NewsAndAnnouncement/AN NOUNCEMENTSTOCK/Exchange/PENG-00016_BEI-PPR_ER_09-2013.pdf

Peranasari, I. A. A. I., \& Dharmadiaksa, I. B. (2014). Perilaku Income Smoothing dan Faktor-Faktor yang Memengaruhinya. E-Jurnal Akuntansi Universitas Udayana, 8(1), 69-82.

Prabayanti, N. L. P. A., \& Yasa, G. W. (2011). Perataan laba (income smoothing) dan Analisis Fakor-Faktor yang Mempengaruhinya. Journal Universitas Udayana, 6(1), 1-28. 
Pradnyandari, A. A. I. R., \& Astika, I. B. P. (2019). Pengaruh Ukuran Perusahaan, Nilai Saham, Financial Leverage, Profitabilitas Pada Tindakan Perataan Laba di Sektor Manufaktur. E-Jurnal Akuntansi Universitas Udayana, 27(1), 149-172.

Pratama, D. F. (2015). Pengaruh profitabilitas, resiko keuangan, nilai perusahaan, struktur kepemilikan dan dividend payout ratio terhadap perataan laba. Journal of Accounting and Investment, 13(1), 35-43.

Rahmawati. (2012). Teori Akuntansi Keuangan. Yogyakarta: Graha Ilmu.

Saeidi, P. (2012). The Relationship between Income Smoothing and Income Tax and Profitability Ratios in Iran Stock Market. Asian Journal of Finance $\mathcal{E}$ Accounting, 4(1), 46-51. https://doi.org/10.5296/ajfa.v4i1.790

Scott, W. . (2003). Financial Accounting Theory (2nd ed.). Canada: Prentice Hall.

Sugiyono. (2017). Metode Penelitian Kuantitatif, Kualitatif, dan RED. Bandung: Alfabeta.

Sulistyanto, H. S. (2008). Manajemen Laba: Teori dan Model Empiris. Jakarta: PT Grasindo.

Sutojo, S., \& Aldridge, E. J. (2008). Good Corporate Governance ( Tata Kelola Perusahaan yang Sehat). Jakarta: PT Famar Mulia Pustaka.

Tsuroyya, M. U., \& Astika, I. B. P. (2017). Pengaruh Profitabilitas Dan Financial Leverage Pada Income Smoothing Dengan Ukuran Perusahaan Sebagai Variabel Pemoderasi. E-Jurnal Akuntansi, 20(3), 2273-2302.

Utama, M. S. (2016). Aplikasi Analisis Kuantitatif (6th ed.). Denpasar: Fakultas Ekonomi Universitas Udayana.

Veronica Indrawan, Sukrisno Agoes, H. P. and O. M. J., \& Popoola. (2018). The Impact of Audit Committee, Firm Size, Profitability, and Leverage on Income Smoothing. Indian-Pacific Journal of Accounting and Finance (IPJAF), 2(1), 61-74.

Watts, R., \& Zimmerman. (1978). Towards a Positive Theory off The Determination of Accounting Standards. The Accounting Review, 53(1), 112134.

Widaryanti. (2009). Analisis Perataan Laba Dan Faktor Yang Mempengaruhi Pada Perusahaan Manufaktur Di Bursa Efek Indonesia. Fokus Ekonomi, 4(2), 60-77.

Wijoyo, D. S. (2014). Variabel-Variabel Yang Mempengaruhi Praktik Perataan Laba Pada Perusahaan Manufaktur Yang Publik. Jurnal Bisnis Dan Akuntasi, 16(1), 37-45. https://doi.org/1410-9875

Yang, C., Murinde, V., \& Ding, X. (2008). Ownership structure, corporate governance and income smoothing in China. WP, Department of Business, Economics \& Management, 86(0), 1-28.

Yanti, N. M. Y. W. A., \& Dwirandra, A. A. N. B. (2019). The effect of profitability in income smoothing practice with good corporate governance and dividend of payout ratio as a moderation variable. International Research Journal of Management, IT and Social Sciences, 6(2), 12-21. https://doi.org/10.21744/irjmis.v6n2.601

Zarnegar, Z., \& Hamidian, M. (2015). Examining the Relationship between Profitability , Financial Leverage and Income Smoothing at Firms Listed on Tehran Stock Exchange. Irian Journal of Business and Economics, 3(3), 80-83. 